\title{
A note on the loss of hydrogen and the supply of hydrogen to the Earth \\ as a direct or indirect effect of the solar wind
}

\author{
N. A. BarRicelet - TR. Metcatee $\left({ }^{*}\right)$
}

Ricevulo il 29 Marzo 1969

\begin{abstract}
SumanY. ... The rate at which hydrogen is supplied to the Earth by the solar wind, and the rate at which hydrogen escapes from the Earth by diffusion into space are compared on the hasis of recent estimates. It is found that the hydrogen supplied by the solar wind is roughly comparable to or may even be larger than present hydrogen losses. The Earth may have lost most of its hydrogen at an early stage when, according to Urey and Miller (1959), Fox (1960) and others, the Earth had a relucing, instead of an oxidizing atmosphere. However, no sufficient evidence is yet available to determine whether the Earth is still losing more hydrogren than it receives. The common notion that the Earth is still in the process of losing its hyclrogen is therefore in question.
\end{abstract}

Riassunto. - Sulla base di recenti stime, si confronta il tasso di idrogeno fornito alla Terra dai venti solari in rapporto al tasso di fuga dellidrogeno dalla Terra in segruito a difhusione nello spazio. Si constata che l'ilrogeno fornito dai venti solari è pressoché pari, forse anzi superiore a quelle che sono le perdite attuali di idrogeno. E da presumere che la Terra abbia perso la maggior parte del proprio idrogeno in uno stadio primario. quando - secondo Vrey e Hiller (1959), Fox (1960) ed altri -.. l'atmosfera della Terra era del tipo riducente, invece che ossidante. Communue, non sono state finora portate prove concludenti per determinare se, tultora, la Terra continui a perdere idrogeno in quantita superiore a quella che riceve. J'ipotesi generalnente accettata, secondo eni il processo di riduzione del contenuto di idrogeno della Terra sarebhe tuttora in corso, è quindi posta in dubbio.

$\left.{ }^{*}\right)$ Iniversity of Washington, Seattle, Washington. 


\section{1. - INTRODCOTOS.}

After the discovery of the substantial intensity of the stream of protons and hydrogen atoms carried by the solar wind, the question las arisen whether the rate at which hydrogen is supplied to the Fanth by the solar wind might be comparable to or larger than the late at which the Easth is losing hydrogen by diflusion into space. Only very rough estimates of the time rates are possible at present, and the main purpose of this note is to attract attention to the problems involved and their possible implications rather then bring a final solution.

\section{2. - Hetmate of IIYdrogen Supplate by Solar Wind.}

Only a high estimate of the rate of hydrogen supplied to the Farth by the solas wind - obtained by disregarding the affect of the Farth's magnetic field on charged particles - seems meaningful on the basis of present information.

According to Jokipii ('), the flux of the solar wind is apploximately $3 \times 10^{\mathrm{s}}$ protons/(-m² sec in the vicinity of the Earth. Other recent estimates (Brigde, ${ }^{2}()$ diller from this by a factor 3 either way. Using the first estimate, the amount of hydrogen from the solar wind which would be intercepted by the Eanth if the Earth did not have a magnetic field or if the solat wind contained a comparable amount of uncharged particles would be:

$$
\begin{gathered}
\left(3 \times 10^{*} \frac{\text { protons }}{\left(\mathrm{m}^{2} \cdot \mathrm{sec}\right)}\left(\frac{1}{6.02 \times 10^{23} \text { protons }}\right)\left(\frac{\mathrm{mm}}{\text { mole of } H}\right)\left(\frac{3.6 \times 10^{3} \mathrm{sec}}{\mathrm{hr}}\right)\right. \\
\left(8760 \frac{\mathrm{hr}}{\mathrm{yr}}\right) \pi R^{2}=\left(1.57 \times 10^{-8} \frac{\mathrm{gm}}{\left(1 \mathrm{~m}^{2} \cdot \mathrm{yr}\right.}\right) \pi R^{2} .
\end{gathered}
$$

(where $R$ is the radius of the Earth).

Because of the Earth's magnetic field and the eflect of the mangetosphere on charged particles, the actual amount of solas-wind-hydrogen which would reach the Earth's atmosphere would be only a fraction of this figure which should therefore be considered as a high estimate. Present, theories and available information give discrepant estimates of 
this fraction and it has not been decided whether this fraction would be substantial or not.

\section{3. - ESTIMATE OF IYYROGEN LOSS HROM EARTII.}

According to Spitzer (3), (table 5, page 245) the time of escape of free hydrogen from the Earth is $3.5 \times 10^{4}$ years, assuming an upper atmosphere temperature of $1000^{\circ} \mathrm{K}$. According to Farley et al. (1) the approximate temperature from 350 to $500 \mathrm{~km}$ is $1000^{\circ} \mathrm{K}$; according to Evans $\left({ }^{5}\right)$ the ion-temperature at about $400 \mathrm{~km}$ is approximately 900\%K. The time of escape is defined as the time in which the amount of hydrogen lost by the Earth would be equal to the amount of hydrogen in its atmosphere on the assumption that the hydrogen concentration in the atmosphere were maintained constant by a contimuous supply.

The amount of hydrogen in the atmosphere per cme of the Earth's surface is $3.5 \times 10^{-5} \frac{\mathrm{gm}}{\mathrm{em}}$ (Hutchinson, $\left.\left({ }^{6}\right)\right)$. Hence the rate of hydrogen loss from the atmosphere is estimated to be:

$$
\begin{aligned}
& \left(3.5 \times 10^{-5} \frac{\mathrm{gm}}{\mathrm{cm}^{2}}\right)\left(\frac{1}{3.6 \times 10^{4} \mathrm{yrs}}\right)\left(4 \pi R^{2}\right)= \\
= & \left(3.9 \times 10^{-9} \frac{\mathrm{gm}}{\mathrm{cm}^{2} \cdot \mathrm{yr}^{2}}\right) \pi R^{2} .
\end{aligned}
$$

(where $R$ is the radius of the Earth).

Comparing this with the high estimate given in part 2 of the hydrogen accumulation shows that the rate of hydrogen gain could be as large as or even larger than the rate of hydrogen loss. Recent work by Chamberlain and Camploll $\left({ }^{7}\right)$ indicates that the rate of hydrogen loss from the atmosphere may be slightly smaller then the value calculated above.

\section{4. - Conclusion.}

In spite of the considerable uncertenity both in the hydrogen loss and the hydrogen supply by the solar wind, the least one can say about the result is that: One camnot tale it for granted that the Earth's present 
hydrogen balance is negative, or in other words that the Earth is still losing more hydrogen than is supplied to it by the solar wind.

This concelusion does not contradict the explanation commonly given to the fact that the Earth as well as the other three terrestrial planets (namely Jars, Venus and Ilereury) have a low content of hydrogen compared with the larger outer planets and the cosmic abundance of this element. The explanation that the Earth's gravitational field is incapable of retaining a large concentration of hydrogen in its atmosphere remains valid. However, the main loss of hydrogen by the Earth must have occurred at the time when the Earth had a reducing instead of an oxydizing atmosphere and probably contained a substantial concentration of hydrogen in its atmosphere (Urey and Miller $\left({ }^{8}\right)$, Fox $\left.\left({ }^{9}\right)\right)$.

The transformation from reducing to oxydizing atmosphere caused by photosynthesis in living systems may have influenced the Earth's hydrogen balance in two different ways:

1 - By binding most atmospheric hydrogen into water, thus preventing it from reaching the upper regions of the atmosphere where it could be lost by diffusion into space.

2 - By supplying a chemical reagent capable of binding a significant portion of the hydrogen carried to the Earth by the solar wind.

Whether at present the net result of these phenomena is still a reduction or a tight balance or even an increase of the Farth's hydrogen is an unresolved question. However the very fact that the two figures are so close to one another that there can be any doubt at all about this point suggests an even balance between hydrogen supplied by the solar wind and hydrogen lost from the Earth. Otherwise one would have expected to find a difference by several orders of magnitude between the two figures, and the facts presented here would be difficult to explain as pure coincidence.

The Earth may be losing approximately the same amount of hydrogen which is being supplied to it by the solar wind, and the concentration of hydrogen, and perhaps even the concentration of water vapor in the mpper stratosphere may basically depend on this hydrogen balance.

\section{ACKNOWLEDGMFNT.}

Thanks are due to Professor Kemneth C. Clark for valuable advice and encouragement. 


\section{REFERFNCES}

(1) Jokipll I. R., Elfects of DifJusion on the Composition of the Solar Corona and the Solar Wind. "The Solar Wind", (Rohert .J. Mackin, Jr., Marcia Nengehaner, eds.) 215. Jet, Propulsion Laboratory, California Institute of Technology, Pasadena, California, (1966).

(2) Bunge II.S., Our linouledge of the Solar Wind. "The Solar Wind", ( Robert J. Mackin, Jr., Marcia Nengebaner, eds.), 127. Jet Porpulsion Laboratory, Califormia Institute of Technology, Pasadena, California, (1966).

(3) Spruen Isyan .Jr., The Terrestrial Atmosphere Above $300 \mathrm{~km}$. "The Atmosphere of the Earth and Planets" (Gerald P. Kuiper, ed.), 245, Table 5. The Cniversity of Chieago Press, Chicago, Illinois, (1947).

(4) Farley D. T., Mcclure J. P., Sterlava D. I., Green J. I., Temperature and Composition of the Equatorial Ionosphere. "Journal of Geophysical Research - Space Physics", 72, 23, 5844-5845, Figs. 5 - 6, (1967).

(5) Evans J. W., Electron Temperature and Lon Composition in the $F_{1}$ Region. "Journal of Geophysical Research - Space Physies", 72, 13, 3350. Figs. 7-10, (1967).

${ }^{(6)}$ Hutcinson (4. D), The Biochemistry of the Terrestrial Atmosphere. "The Earth as a Planet" (Gerald P. Kuiper, ed.), 372, Table 1, The Vuiversity of Chicago Press, Chicago, Illinois, (1954).

(7) Ciramberlain .J. W., Canpibel. F. J., Rate of Evaporation of a non-Maxwellian Atmosphere. "Astrophysical Journal", Chicago, 149, 687-705, (1967).

$\left.{ }^{(}\right)$UREY II. C., MILLER E. L., Organic compound synthesis on the primitive Earth. "Science Csss", 245-251, (1959).

(") Fox S. W., How did life Begin? Recent experiments suggest an integrale origin of anabolis, protein and cell boundaries. "Science", CXXXII, 20()-208, (1960). 